\title{
Livor mortis pada keracunan insektisida golongan organofosfat di kelinci
}

\author{
${ }^{1}$ Chrissy A. A. Thanos \\ ${ }^{2}$ Djemi Tomuka \\ ${ }^{2}$ Nola T. S. Mallo
}

\author{
${ }^{1}$ Kandidat Skripsi Fakultas Kedokteran Universitas Sam Ratulangi Manado \\ ${ }^{2}$ Bagian Ilmu Kedokteran Forensik \& Medikolegal Fakultas Kedokteran \\ Universitas Sam Ratulangi - RSUP Prof. Dr. R. D. Kandou Manado \\ Email: chrissythanos19@gmail.com
}

\begin{abstract}
The objective of this study is to compare the time livor mortis formed, fixed, and colored on the control group and treated group. This was a true experimental study with a post-test only control group design. This study was conducted at the Forensic Laboratory Prof. Dr. R. D. Kandou Hospital Manado from September to December 2015. Samples were 10 rabbits (Oryctolagus cuniculus) of 1250-2100 g, divided into two groups, the control group and the treated group. The treated group was exposed to diazinon as many as $3 \mathrm{ml}$ in one treatment. Data were analyzed by using univariat analysis, subsequently tested using Independent $t$-Test. The results showed that there was no significant difference $(p>0.05)$ on the time livor mortis formed and fixed between the control group and the treated group. There is a slight color difference of the livor mortis between control group (bluish-violet/purple) and treated group (purplish-red). Conclusion: There was no significant difference on the time of livor mortis formed and fixed between rabbits with and without organophosphate intoxication. There was a slight difference in color of livor mortis between rabbits with organophosphate intoxication (purplish-red) and the ones without intoxication (bluish-violet/purple).
\end{abstract}

Keywords: livor mortis, intoxication, organophosphate, rabbits

\begin{abstract}
Abstrak: Penelitian ini bertujuan untuk membandingkan waktu terbentuk, waktu menetap dan warna livor mortis pada kelompok kontrol dan kelompok perlakuan. Jenis penelitian eksperimen murni (true experimental desain) dengan rancangan penelitian post test only control group design. Penelitian dilakukan di Laboratorium Forensik RSUP Prof. Dr. dr. R. D. Kandou Manado pada bulan September - Desember 2015. Sampel terdiri dari 10 ekor kelinci (Oryctolagus cuniculus) dengan berat badan 1250-2100g yang dibagi menjadi kelompok kontrol dan perlakuan. Kelompok perlakuan dilakukan pemaparan diazinon sebanyak $3 \mathrm{ml}$ dalam satu kali pemberian. Data dianalisis dengan analisis univariat kemudian diuji dengan Independent $t$-Test. Hasil penelitian menunjukkan tidak terdapat perbedaan bermakna $(\mathrm{p}>0,05)$ waktu terbentuk dan waktu menetap livor mortis antara kelompok kontrol dan kelompok perlakuan. Terdapat sedikit perbedaan warna livor mortis antara kelompok kontrol (biru keunguan) dan kelompok perlakuan (ungu kemerahan/livide). Simpulan: Tidak terdapat perbedaan bermakna waktu terbentuk dan waktu menetap livor mortis antara kelinci dengan dan tanpa keracunan organofosfat. Terdapat sedikit perbedaan warna livor mortis antara kelinci dengan keracunan organofosfat (ungu kemerahan/livide) dan yang tanpa keracunan (biru keunguan).
\end{abstract}

Kata kunci: livor mortis, keracunan, organofosfat, kelinci

Ilmu kedokteran forensik sangat bermanfaat bagi bidang peradilan dan bidang-bidang lain yang tidak berhubungan dengan peradilan. Pemeriksaan forensik 
digunakan untuk menentukan lama kematian, penyebab kematian serta mekanisme kematian suatu individu. Penentuan lama waktu kematian dapat diperkirakan dengan perubahan-perubahan yang terjadi pada tubuh. Memperkirakan saat kematian yang mendekati ketepatan mempunyai arti penting terutama bila dikaitkan dengan proses penyidikan. ${ }^{1}$

Menurut Undang-Undang Republik Indonesia Nomor 36 Tahun 2009 Tentang Kesehatan, Pasal 117: "Seseorang dinyatakan mati apabila fungsi sistem jantung, sirkulasi dan sistem pernafasan terbukti telah berhenti secara permanen, atau apabila kematian batang otak telah dapat dibuktikan.” Mekanisme kematian timbul akibat abnormalitas dari aspek biokimia dan fisiologi tubuh yang berujung pada kematian. ${ }^{1}$

Tanda-tanda kematian dibagi dua yaitu kematian pasti dan tidak pasti. Tanda kematian tidak pasti ialah pernafasan berhenti, sirkulasi terhenti, kulit pucat, tonus otot menghilang dan relaksasi, pembuluh darah retina mengalami segmentasi dan pengeringan kornea. Sedangkan tanda pasti kematian ialah lebam mayat (livor mortis), kaku mayat (rigor mortis), penurunan suhu tubuh (algor mortis), pembusukan, mumifikasi dan adiposera. ${ }^{1,2}$

Toksikologi forensik merupakan salah satu cabang ilmu forensik yang mempelajari tentang zat kimia atau racun yang dapat mengancam hidup serta mengintepretasikan temuan analisis dalam suatu argumentasi tentang penyebab keracunan. ${ }^{3}$

Menurut World Health Organization (WHO), satu juta kasus keracunan berat dan dua juta kasus bunuh diri menggunakan organofosfat terjadi di seluruh dunia dan 200.000 diantaranya meninggal. ${ }^{4} \quad$ WHO memperkirakan kejadian keracunan insektisida akut sebanyak 3.000.000 kasus setiap tahunnya dengan angka kematian sejumlah 220.000 kasus. Mayoritas insiden ini terjadi di negara-negara berkembang, terutama di Afrika, Asia, Amerika tengah dan Amerika
Selatan. ${ }^{5}$ Self Poisoning (meracuni diri) dengan berbagai zat mulai dari obat-obatan, pestisida hingga produk rumah tangga yang tersedia adalah metode paling umum yang dilakukan, dengan proporsi $70 \%$ di Sri Langka, 55\% di Bangladesh, 47\% di Indonesia, 37\% di India, 23\% di Thailand. ${ }^{6}$ Berdasarkan laporan WHO 2006, metode yang paling sering digunakan di Indonesia untuk kasus bunuh diri yaitu dengan meracuni diri (47\%), diikuti dengan menggantung diri (46\%) dan melompat dari ketinggian (11\%). ${ }^{7}$ Keracunan yang disengaja (terutama untuk upaya percobaan bunuh diri atau berhasil bunuh diri), proporsinya dalam kasus keracunan pestisida cukup besar di Negara tertentu. ${ }^{8}$ Organofosfat merupakan racun pembasmi serangga yang paling toksik yang mudah diperoleh di pasaran.

Pada penelitian ini, sampel yang ideal ialah sampel yang didapat dari pemeriksaan jenazah, akan tetapi karena keterbatasan dalam mendapatkan jenazah maka dengan tidak mengurangi keilmiahan, peneliti menggunakan hewan coba yaitu kelinci sehat. Kelinci mudah didapatkan dan secara morfologi lebih besar dibandingkan tikus sehingga diharapkan secara teknis lebih mudah.

Penelitian sebelumnya tentang karakteristik intoksikasi organofosfat telah banyak dilakukan, namun penelitian terhadap livor mortis yang terbentuk pada korban intoksikasi organofosfat yang meninggal belum pernah dilakukan sebelumnya. Berdasarkan hal tersebut, peneliti ingin mengetahui waktu terbentuk, waktu menetap dan warna livor mortis pada kasus keracunan organofosfat, maka peneliti tertarik melakukan penelitian mengenai livor mortis pada intoksikasi insektisida golongan organofosfat pada kelinci.

\section{KERACUNAN}

Keracunan merupakan masuknya suatu zat ke dalam tubuh yang dapat mengakibatkan gangguan kesehatan serta kematian. Keracunan akibat insektisida sudah menjadi masalah seluruh dunia. 
Estimasi jumlah kasus per tahun sebesar 13 juta. Angka kematian beragam mulai dari $1 \%$ sampai $9 \%$ kasus yang datang berobat, dan bergantung pada ketersediaan antidote serta mutu layanan medis yang diberikan. Keracunan yang disengaja (terutama untuk upaya percobaan bunuh diri atau berhasil bunuh diri) proporsinya dalam kasus keracunan insektisida cukup besar di Negara tertentu. ${ }^{9}$

Racun masuk ke dalam tubuh melalui berbagai cara yaitu ${ }^{10}$ :

a. Ditelan (per oral; ingesti): Portal entri ini sering dan mudah terjadi namun bahan asing yang masuk tidak akan mudah mencapai peredaran darah karena beberapa hal penting yang terkait pada fungsi saluran gastro intestinal. Di mulut xenobiotik bercampur dengan ludah yang mengandung enzim, di dalam lambung xenobiotik yang tidak tahan asam akan dihancurkan oleh asam lambung, di usus halus akan bertemu dengan enzim usus halus yang bersifat basa sehingga xenobiotik asam akan ternetralisir, dan seterusnya hingga terbuang melalui usus besar. Proses absorpsi terjadi melalui mukosa usus, yang selanjutnya mengalir melalui system sirkulasi darah. ${ }^{11}$

b. Terhisap bersama udara pernafasan (inhalasi): Bukti mengenai efek yang serius akibat pajanan melalui udara terhadap kesehatan manusia masih sangat sedikit. $^{12}$

c. Melalui penyuntikan (parenteral; injeksi)

d. Penyerapan melalui kulit (absorpsi): Pajanan xenobiotik melalui kulit terjadi ketika xenobiotik mengenai kulit atau terbawa angin hingga menempel di kulit. Semakin luas area kulit yang terkena dan semakin lama durasi kontak maka semakin serius dampak yang akan terjadi. ${ }^{11}$ Toksisitas melalui kulit (acute dermal toxicity) dapat terjadi jika xenobiotik diabsorpsi kulit, menembus epidermis, kemudian memasuki kapiler darah dalam kulit, sehingga terbawa sampai paru-paru dan organ vital lainnya seperti otak dan otot. ${ }^{13}$
Xenobiotik akan segera diabsorpsi jika kontak melalui kulit atau mata. Absorpsi ini akan terus berlangsung selama pestisida masih ada pada kulit. Kecepatan absorpsi berbeda pada tiap bagian tubuh. Perpindahan residu pestisida akan menambah potensi keracunan. $^{14}$

e. Melalui anus atau vagina (perektal; pervaginam)

\section{ORGANOFOSFAT}

Organofosfat merupakan insektisida yang paling toksik diantara jenis pestisida lainnya dan sering menyebabkan keracunan pada manusia. ${ }^{15}$ Organofosfat bekerja sebagai racun kontak, racun perut, dan racun pernafasan. ${ }^{16,17}$ Dalam jumlah sedikit organofosfat dapat menyebabkan kematian, tetapi diperlukan lebih dari beberapa mg untuk menyebabkan kematian pada orang dewasa. Organofosfat memiliki struktur kimia dengan atom oksigen atau sulfur yang berikatan ganda dengan fosfor, sehingga disebut phosphate atau phosphorothioates. Sebagian besar senyawa organofosfat berikatan sulfur, karena bentuk $\mathrm{P}=\mathrm{S}$ lebih stabil dan larut lemak. $^{18}$

Insektisida golongan organofosfat yang tidak membutuhkan aktivitas metabolik yang disebut juga dengan inhibitor langsung yang dapat menghasilkan efek toksik pada daerah kontak langsung, seperti keringat (berhubungan langsung dengan kulit), miosis atau pupil pinpoint (kontak dengan mata), dan/atau bronkospasme (kontak dengan pernafasan). Pada insektisida golongan organofosfat, ada organofosfat dengan inhibisi langsung (yang mengandung $=\mathrm{O}$ ) dan organofosfat dengan inhibisi tak langsung (yang mengandung $=S$ ) tergantung dibutuhkan atau tidaknya pengaktifan metabolik sebelum terjadinya hambatan pada asetilkolinesterase. Senyawa organofosfat indirek harus menjalani bioaktivasi sehingga menjadi aktif secara biologi. Senyawa organofosfat indirek contohnya parathion, diazinon, malathion, dan chlorpyrifos menjadi lebih toksik 
dibandingkan senyawa induknya. ${ }^{19}$

Tanda dan gejala akut dari intoksikasi organofosfat berhubungan dengan inhibisi asetilkolinesterase. Manifestasi klinik dari kontak dengan senyawa organofosfat berupa: ${ }^{17,20}$

a. Efek muskarinik (sistem parasimpatis) termasuk keringat, hipersalivasi, hiperlakrimasi, bronkospasme, dyspnea, gejala gastrointestinal (mual, muntah, keram abdomen, dan diare), miosis (pupil pinpoint), penglihatan kabur, inkontinensia urin, wheezing, bradikardi.

b. Efek nikotinik (sistem saraf simpatis dan motorik) termasuk hipertensi, fasikulasi otot, keram otot, kelemahan motorik, takikardi, dan paralisis.

c. Efek CNS termasuk kecemasan, pusing, insomnia, mimpi buruk, sakit kepala, tremor, bingung, ataksia, koma.

Tanda dan gejala dari intoksikasi organofosfat ini dapat digambarkan dalam DUMBELS: Diare, Urination, Miosis, Bronkospasme, Emesis, Lakrimasi, Salivasi. Tanda dan gejala dari intoksikasi ini tidak akan terjadi kecuali aktivitas kolineterase sekitar 50 persen atau kurang dari aktifitas normalnya. ${ }^{19}$

Takaran fatal untuk golongan organofosfat, Malathion 1-5 gram; Parathion $10 \mathrm{mg} / \mathrm{kgBB}$; Systox $100 \mathrm{mg}$; dan tetraetilpirofosfat $0,4 \mathrm{mg} / \mathrm{kgBB} .{ }^{2}$ Dosis letal sulit ditentukan oleh karena berbagai faktor yang mempengaruhi kerja racun. Oleh karena itu, dosis racun yang digunakan ialah Approximately Fatal Dose (AFD) yang membantu dokter untuk menilai prognosis suatu kasus. AFD bisa disebut juga dengan

Usual Fatal Dose (UFD). Biasanya UFD berdasarkan pada Minimum Lethal Dose (MLD) yang umumnya merupakan indikasi dosis letal pada $50 \%$ dari hewan (LD50). UFD pada organofosfat jenis Diazinon adalah $0.1 \mathrm{gm}$ untuk orang dewasa. $^{21}$

Toksisitas didefinisikan sebagai $\mathrm{LD}_{50}$ yang dinyatakan dalam mg senyawa pestisida per kilogram berat badan, dalam perkataan lain dosis yang dapat membunuh $50 \%$ persen dari jumlah hewan percobaan yang digunakan pada kondisi laboratorium. $\mathrm{LD}_{50}$ dapat dinyatakan dengan oral (melalui mulut atau diletakan dalam perut tikus), melalui kulit (digunakan terhadap kulit tikus atau kelinci), dan melalui pernapasan. Besarnya konsentrasi (dosis) merupakan faktor yang sangat penting di dalam menentukan bahaya atau tidaknya suatu jenis pestisida/bahan kimia. Di samping toksisitas, variabel lainnya yang cukup penting ialah dosis, lamanya terkena pestisida, dan caranya masuk ke dalam badan. Jumlah pestisida yang dibutuhkan untuk membunuh manusia dapat dihubungkan dengan $\mathrm{LD}_{50}$ dari senyawa kimia terhadap tikus di laboratorium. ${ }^{22}$

\section{LIVOR MORTIS}

Livor Mortis (Postmortem Lividity, Postmortem Stains, Postmortem Hypostatis, Postmortem Suggillation, Postmortem Vibices, lebam mayat) yaitu warna ungu kemerahan (livide) pada bagian tubuh terendah akibat akumulasi darah di pembuluh darah kecil di bagian tubuh yang paling rendah akibat gravitasi. Livor Mortis yang berwarna kebiruan kadang-kadang disalah artikan sebagai memar. ${ }^{23}$

Livor Mortis terbentuk pada daerah tubuh yang menyokong berat badan tubuh seperti bahu, punggung, bokong, betis pada saat terbaring diatas permukaan yang keras akan tampak pucat yang terlihat kontras dengan warna livor mortis disekitarnya akibat dari kompresi pembuluh darah di daerah ini yang mencegah akumulasi darah. ${ }^{23}$ Livor Mortis terbentuk saat terjadi kegagalan sirkulasi darah, pada saat arteri rusak dan aliran balik vena gagal mempertahankan tekanan hidrostatik yang menggerakan darah mencapai capillary bed yaitu tempat pembuluh-pembuluh darah kecil afferen dan efferen saling berhubungan. Darah dan sel-sel darah terakumulasi memenuhi saluran tersebut dan sukar dialirkan ke daerah tubuh lainnya. ${ }^{24,25}$ Sel darah merah (eritrosit) akan bersedimentasi melalui jaringan longgar, tetapi plasma akan berpindah ke 
jaringan longgar yang menyebabkan terbentuknya edema setempat, menimbulkan blister pada kulit. Dari luar akan terlihat bintik-bintik berwarna merah kebiruan atau adanya eritrosit pada daerah terendah terlihat dengan timbulnya perubahan warna kemerahan pada kulit yang disebut livor mortis. ${ }^{2}$ Pada tahap awal pembentukannya, livor mortis memiliki warna kemerahan yang dihasilkan dari jumlah eritrosit yang membawa hemoglobin yang teroksidasi. Meningkatnya interval post mortem, akan mengakibatkan perubahan warna menjadi lebih gelap. Warna normal livor mortis ialah merah keunguan. Warna merah keunguan ini akan berubah menjadi warna ungu akibat hasil pemisahan oksigen dari hemoglobin eritrosit post mortem dan konsumsi oksigen terus-menerus oleh selsel yang awalnya mempertahankan fungsi sistem kardiovaskuler (misalnya sel-sel hati yang mempertahankan fungsi kardiovaskuler selama kira-kira 40 menit dan sel otot rangka antara 2 sampai 8 jam). Produk Deoxyhemoglobin yang dihasilkan akan mengubah warna biru keunguan menjadi warna ungu. ${ }^{27}$

Terdapat 3 faktor yang mempengaruhi livor mortis, yaitu : ${ }^{23}$

a. Volume darah yang beredar

1) Banyak (CHF) : livor mortis cepat, luas

2) Kurang (anemia) : livor mortis lama, terbatas

b. Lamanya darah dalam keadaan cepat cair

c. Warna livor mortis: ${ }^{23,26}$

1) Normal

2) Keracunan gas CO: warna merah bata/ Cherry red

3) Keracunan $\mathrm{CN}$ : warna merah terang/ Bright red

4) Keracunan anillin, nitrobenze: warna coklat kebiruan

5) Keracunan phosphorus: coklat tua/ Dark Brown

6) Asfiksia: Dark red

Livor mortis mulai tampak 20-30 menit postmortem, semakin lama intensitasnya bertambah dan menetap setelah 8-12 jam. ${ }^{2}$ Menetapnya livor mortis disebabkan oleh karena terjadinya perembesan darah ke dalam jaringan sekitar akibat rusaknya pembuluh darah akibat tertimbunnya sel-sel darah dalam jumlah yang banyak, adanya proses hemolisa selsel darah dan kekakuan otot-otot dinding pembuluh darah. Dengan demikian penekanan pada daerah terbentuknya livor mortis yang dilakukan setelah 8-12 jam tidak akan menghilang. Hilangnya livor mortis pada penekanan dengan ibu jari memberi indikasi bahwa livor mortis belum terfiksasi secara sempurna. ${ }^{25}$

Setelah 4 jam, kapiler-kapiler akan mengalami kerusakan dan butir-butir darah merah juga akan rusak. Pigmen-pigmen dari pecahan darah merah akan keluar dari kapiler yang rusak akan mewarnai jaringan di sekitarnya sehingga menyebabkan warna livor mortis akan menetap serta tidak hilang jika ditekan dengan ujung jari atau jika posisi mayat dibalik. Jika pembalikan posisi dilakukan setelah 12 jam dari kematiannya. Maka livor mortis baru tidak akan timbul pada posisi terendah, karena darah sudah mengalami koagulasi. ${ }^{25}$

\section{LIVOR MORTIS DAN INTOKSIKASI ORGANOFOSFAT}

Livor mortis sering berwarna merah padam, tetapi bervariasi, tergantung oksigenasi sewaktu korban meninggal. Bila terjadi bendungan/hipoksia, livor mortis yang lebih gelap karena adanya hemoglobin tereduksi dalam pembuluh darah kulit. Livor mortis merupakan indikator yang kurang akurat dalam menentukan mekanisme kematian. Kematian dengan sebab wajar oleh karena gangguan coroner atau penyakit lain memiliki livor mortis yang lebih gelap. ${ }^{26}$

Organofosfat menghambat aksi pseudokolinesterase dalam plasma dan kolinesterase dalam sel darah merah dan pada sinapsisnya. Penghambatan kerja enzim terjadi karena organofosfat melakukan fosforilasi enzim tersebut dalam bentuk komponen yang stabil. Enzim tersebut secara normal menghidrolisis asetilkolin menjadi asetat dan kolin. Pada 
Thanos, Tomuka, Mallo: Livor pada intoksikasi..

saat enzim dihambat, mengakibatkan jumlah asetilkolin meningkat dan berikatan dengan reseptor muskarinik dan nikotinik pada sistem saraf pusat dan perifer. ${ }^{15}$

Organofosfat bekerja sebagai racun kontak, racun perut, dan racun pernafasan. ${ }^{16,17}$ Intoksikasi insektisida golongan organofosfat menyebabkan terjadinya kegagalan pernafasan, salah satu efek dari organofosfat ialah bronkospasme/bronkokonstriksi, sehingga oksigen tidak dapat masuk ke dalam paruparu. Hal ini menyebabkan asfiksia karena kadar $\mathrm{CO}_{2}$ lebih tinggi daripada kadar $\mathrm{O}_{2}$ dalam darah. ${ }^{2}$

Pada pemeriksaan luar jenazah dapat ditemukan: ${ }^{2}$

1. Sianosis pada bibir, ujung-ujung jari dan kuku.

2. Pembendungan sistemik maupun pulmoner dan dilatasi jantung kanan merupakan tanda klasik pada kematian akibat asfiksia.

3. Warna livor mortis merah-kebiruan gelap dan terbentuk lebih cepat. Distribusi livor mortis lebih luas akibat kadar karbondioksida yang tinggi dan aktivitas fibrinolisin dalam darah sehingga darah sukar membeku dan mudah mengalir.

4. Terdapat busa halus pada hidung dan mulut yang timbul akibat peningkatan aktivitas pernapasan pada fase 1 yang disertai sekresi selaput lendir saluran napas bagian atas. Keluar masuknya udara yang cepat dalam saluran sempit akan menimbulkan busa yang kadangkadang bercampur darah akibat pecahnya kapiler. Kapiler yang lebih mudah pecah yaitu kapiler pada jaringan ikat longgar, misalnya pada konjungtiva bulbi, palpebra dan subserosa lain. Kadang-kadang dijumpai pula di kulit wajah.

5. Gambaran pembendungan pada mata berupa pelebaran pembuluh darah konjungtiva bulbi dan palpebra yang terjadi pada fase 2. Akibatnya tekanan hidrostatik dalam pembuluh darah meningkat terutama dalam vena, venula dan kapiler. Selain itu, hipoksia dapat merusak endotel kapiler sehingga dinding kapiler yang terdiri dari selapis sel akan pecah dan timbul bintik-bintik perdarahan yang dinamakan sebagai Tardieu's spot. Tardieu's spot ini timbul karena permeabilitas kapiler yang meningkat akibat hipoksia.

\section{METODE PENELITIAN}

Penelitian ini merupakan penelitian eksperimen murni (true experimental desain) dengan rancangan penelitian post test only control group design. Penelitian ini dilakukan di Laboratorium Forensik RSUP Prof. Dr. dr. R. D. Kandou Manado pada bulan September - Desember 2015.

Populasi dan sampel adalah keseluruhan obyek penelitian yaitu kelinci dewasa species Oryctolagus cuniculus dengan berat badan 1250-2100 gram, diambil secara incidental sampling sebanyak 10 ekor dibagi dalam 2 kelompok secara random masing-masing kelompok terdiri dari 5 kelinci kelompok kontrol dan kelompok perlakuan. Livor mortis diamati saat awal mulai terlihat perubahan warna setelah kematian kemudian dicatat sebagai waktu terbentuk livor mortis. Waktu livor mortis menetap dicatat saat livor mortis tidak memucat pada penekanan selama 30 detik.

\section{HASIL PENELITIAN}

Hasil analisis univariat variabel dari seluruh sampel penelitian menurut berat badan, waktu terbentuk livor mortis, waktu menetap livor mortis dapat dilihat pada Tabel 1. Tabel 2 menjelaskan tentang perbandingan waktu terbentuk livor mortis pada kelompok kontrol dan kelompok perlakuan. Pada tabel 3 dapat dilihat perbandingan waktu menetap livor mortis pada kelompok kontrol dan kelompok perlakuan.

Hasil analisis statistik dengan menggunakan unpaired t-test pada waktu terbentuk livor mortis dapat dilihat bahwa nilai $t_{\text {hitung }}=0,355<$ nilai $t_{\text {tabel }} 1,860$ dengan nilai signifikansi $p=0,732$ didapatkan P Value (Asymp. Sig.2-tailed) 
$>0,05$ sehingga Hipotesis null $\left(\mathrm{H}_{0}\right)$ diterima dengan kesimpulan tidak terdapat perbedaan signifikan waktu terbentuk livor mortis antara kelompok kontrol dan kelompok perlakuan. Hasil analisis pada waktu menetap livor mortis dapat dilihat bahwa nilai $t_{\text {hitung }}=0,815<$ nilai $t_{\text {tabel }} 1,86$ dengan nilai signifikansi $p=0,439$ didapatkan P Value (Asymp. Sig.2-tailed) $>0,05$ sehingga Hipotesis null $\left(\mathrm{H}_{0}\right)$ diterima dengan kesimpulan tidak terdapat perbedaan signifikan waktu menetap livor mortis antara kelompok kontrol dan kelompok perlakuan.

Penilaian secara makroskopik dimulai pada waktu kematian melalui pengamatan warna livor mortis yang terlihat dan warna livor mortis saat menetap. Sedikit perbedaan yang terlihat pada warna livor mortis, kelompok kontrol negatif berwarna biru keunguan, sedangkan pada kelompok perlakuan berwarna ungu kemerahan.

\section{BAHASAN}

Hasil penelitian ini (Tabel 1) didapatkan bahwa rerata waktu terbentuk livor mortis pada keseluruhan sampel adalah 53,30 menit. Hasil penelitian ini (tabel 1) juga menunjukkan rerata waktu menetap livor mortis dari keseluruhan sampel adalah 348,90 menit. Hal ini menunjukkan perbedaan antara waktu terbentuk livor mortis pada kelinci dan manusia. Berdasarkan penelitian yang dilakukan oleh Rayamane, dkk (2014) waktu livor mortis pada manusia terbentuk dalam waktu 1-2 jam setelah kematian dalam bentuk bintik-bintik dan bercak kecil, penelitian ini juga menyatakan livor mortis pada manusia setelah 2-4 jam mulai terbentuk bercak yang lebih besar, 4-6 jam kemudian terbentuk bercak yang homogen dan livor mortis mulai terfiksasi/menetap dalam waktu 7-9 jam setelah kematian. ${ }^{28}$

Hasil penelitian ini didapatkan pada waktu terbentuk dan menetap livor mortis pada kelinci lebih cepat dibandingkan waktu terbentuk dan menetap livor mortis pada manusia. Hal ini, mungkin terjadi karena luas penampang tubuh kelinci yang lebih kecil dibandingkan manusia sehingga saat terjadi kegagalan sirkulasi pembentukan livor mortis menjadi lebih cepat. $^{31}$

Penelitian ini didapatkan bahwa rerata waktu terbentuk livor mortis pada kelompok kontrol (56,60 menit) lebih tinggi daripada kelompok perlakuan (50 menit) tetapi secara statistik tidak terdapat perbedaan yang bermakna dengan $p>0,05$ $(p=0,732)$. Penelitian ini juga ditemukan bahwa rerata waktu menetap livor mortis pada kelompok kontrol (368,40 menit) lebih tinggi daripada kelompok perlakuan (329,40 menit), tetapi secara statistik tidak terdapat perbedaan yang bermakna dengan $p>0,05 \quad(p=0,439)$ antara waktu menetap livor mortis dan kelompok kontrol dengan kelompok perlakuan.

Tabel 1. Karakteristik seluruh sampel

\begin{tabular}{llll}
\hline Variabel & $\mathrm{n}(\%)$ & Mean \pm SD & Median (min-max) \\
\hline Kelompok Kontrol & $5(50 \%)$ & - & - \\
Kelompok Perlakuan & $5(50 \%)$ & - & - \\
BB (gram) & - & $1560 \pm 223,358$ & $1500(1250-2100)$ \\
$\begin{array}{l}\text { Waktu terbentuk livor } \\
\text { mortis (menit) }\end{array}$ & - & $53,30 \pm 27,905$ & $50(20-113)$ \\
$\begin{array}{l}\text { Waktu menetap livor mortis } \\
\text { (menit) }\end{array}$ & - & $348,90 \pm 74,270$ & $321(270-486)$ \\
\hline
\end{tabular}


Thanos, Tomuka, Mallo: Livor pada intoksikasi..

Tabel 2. Perbandingan waktu terbentuk livor mortis antara kelompok kontrol dan kelompok perlakuan

\begin{tabular}{llc}
\hline & \multicolumn{2}{l}{ Waktu Terbentuk Livor Mortis (menit) } \\
\cline { 2 - 3 } & Kontrol & Perlakuan \\
\hline Mean & 56,60 & 50,00 \\
Median & 35,00 & 50,00 \\
SD & 41,380 & 3,536 \\
Min-Max & $20-113$ & $45-55$ \\
\hline \multicolumn{2}{c}{} \\
\hline
\end{tabular}

Tabel 3. Perbandingan waktu menetap livor mortis antara kelompok kontrol dan kelompok perlakuan

\begin{tabular}{lll}
\hline & \multicolumn{2}{l}{ Waktu Menetap Livor Mortis (menit) } \\
\cline { 2 - 3 } & Kontrol & Perlakuan \\
\hline Mean & 368,40 & 329,40 \\
Median & 306 & 324 \\
SD & 105,22 & 18,050 \\
Min-Max & $270-486$ & $315-360$ \\
\hline \multicolumn{2}{c}{$p=0,439$} \\
\hline
\end{tabular}

Mekanisme intoksikasi akut Diazinon dalam tubuh yaitu memberikan efek inhibisi terhadap enzim asetilkolinesterase dengan melakukan fosforilasi terhadap enzim tersebut dalam bentuk stabil. Asetilkolin tidak terhidrolisis sehingga jumlahnya meningkat dan mempengaruhi saraf parasimpatis sehingga menyebabkan efek yang luas seperti vasokontriksi pembuluh darah, bronkospasme, dyspnea, hipertensi, takikardia, keram otot, fasikulasi otot, dll. Pada keadaan ini terjadi kegagalan pernafasan mulai dari depresi pusat pernafasan, paralisis otot-otot pernafasan, sekresi bronkial berlebihan, edema pulmonal dan bronkokonstriksi sehingga kelinci perlakuan mengalami kematian oleh karena asfiksia. ${ }^{20}$

Pada keadaan asfiksia oksigen tidak dapat masuk ke paru-paru sehingga kadar $\mathrm{CO}_{2}$ dalam darah meningkat dan aktivitas fibrinolisin akan menyebabkan darah sulit membeku dan mudah mengalir.

Tingginya aktivitas fibrinolisin pada darah berhubungan dengan cepatnya proses kematian. Pembentukan livor mortis menjadi lebih cepat karena meningkatnya fragilitas/permeabilitas kapiler dan terhambatnya pembekuan darah. ${ }^{2}$ Pada asfiksia fibrinogen darah banyak yang hilang namun darah akan tetap mencair dan ini memengaruhi pembentukan livor mortis. Pada kematian wajar (kontrol negatif), darah dapat menjadi permanent incoagulable oleh karena adanya aktivitas fibrinolisin yang dilepas kedalam aliran darah selama proses kematian. Sumber fibrinolisin ini tidak diketahui tetapi kemungkinan berasal dari endothelium pembuluh darah, dan permukaan serosa pada pleura. Aktivitas fibrinolisin ini nyata sekali pada kapilerkapiler yang berisi darah sehingga livor mortis akan menetap dengan cepat. ${ }^{32}$ Darah pada kematian wajar mengalami permanent incoagulable menyebabkan tidak adanya perbedaan bermakna antara kelompok kontrol dan kelompok perlakuan.

Hasil penelitian ini didapatkan livor mortis yang terbentuk pada kelompok kontrol menunjukkan warna biru keunguan sedangkan livor mortis terbentuk pada kelompok perlakuan dengan pemberian Diazinon sebanyak $3 \mathrm{ml}$ selama satu kali dalam sehari menunjukkan warna ungu kemerahan. Penelitian lain menyatakan, warna livor mortis yang terbentuk akibat intoksikasi organofosfat adalah tidak berbeda dengan livor mortis yang terbentuk 
pada kematian umumnya yaitu livide. ${ }^{29,30}$ Hasil penelitian ini didapatkan pada kelompok perlakuan adalah warna ungu kemerahan. Hal ini tidak sesuai dengan teori, secara teori pada kasus asfiksia, kadar karbondioksida tinggi dalam darah menyebabkan sianosis dan warna livor mortis yang terbentuk lebih gelap/Dark red. ${ }^{26}$ Warna dark red disebabkan terjadinya bendungan dan sianosis (kurang $\mathrm{O}_{2}$, karena pelepasan $\mathrm{O}_{2}$ ke jaringan dihambat). Pada penelitian warna merah yang terbentuk lebih terang mungkin juga disebabkan oleh petekie/bintik perdarahan. Bintik perdarahan terjadi karena timbulnya peningkatan permeabilitas kapiler dan juga karena rusak/pecahnya dinding endotel kapiler akibat hipoksia. Bintik perdarahan ini lebih mudah terjadi pada jaringan longgar, seperti misalnya jaringan bawah kelopak mata, atau organ dengan membran transparan (pleura, perikardium), umumnya bintik perdarahan terjadi akibat pelebaran kapiler darah setempat. ${ }^{2}$ Perut kelinci memiliki kulit yang sangat tipis dimana terdapat banyak vaskularisasi, sehingga warna livor mortis yang terbentuk pada kelompok perlakuan menunjukkan warna yang lebih merah akibat pelebaran pembuluh darah kapiler sekitar oleh karena asfiksia.

Hasil penelitian ini juga didapatkan warna livor mortis yang terlihat pada kelompok kontrol menunjukkan warna biru keunguan tidak sesuai dengan teori yaitu warna normal livor mortis ialah ungu kemerahan yang dihasilkan dari jumlah eritrosit yang membawa hemoglobin yang teroksidasi. Warna ungu kemerahan ini akan berubah menjadi warna ungu akibat hasil pemisahan oksigen dari hemoglobin eritrosit post mortem. Meningkatnya interval post mortem maka warna yang terlihat akan lebih gelap. $^{27}$

Berdasarkan hasil penelitian, pada 6 jam setelah kematian kedua kelompok menunjukkan hasil yang sama saat dilakukan penekanan pada livor mortis yang sudah terbentuk selama 30 detik, keduanya tidak menunjukkan adanya perubahan (memucat), hal ini menandakan bahwa livor mortis sudah menetap. Pada manusia livor mortis mulai terfiksasi 7-9 jam setelah kematian. $^{28}$ Livor mortis pada kelinci terfiksasi dengan cepat kemungkinan karena ukuran tubuh kelinci yang lebih kecil dibandingkan manusia. Saat diamati pada 12 jam dan 24 jam setelah kematian, livor mortis pada kelinci kelompok perlakuan dan kontrol membentuk warna yang lebih gelap dibandingkan pada awal terbentuknya livor mortis. Perubahan warna setelah livor mortis terlihat disebabkan oleh hasil pemisahan oksigen dari hemoglobin eritrosit post mortem dan konsumsi oksigen terusmenerus oleh sel-sel yang awalnya mempertahankan fungsi sistem kardiovaskuler. Produk Deoxyhemoglobin yang dihasilkan akan mengubah warna biru keunguan menjadi warna ungu/lebih gelap. ${ }^{27}$

\section{SIMPULAN}

Berdasarkan hasil penelitian dan bahasan dapat disimpulkan bahwa tidak terdapat perbedaan bermakna waktu terbentuk dan waktu menetap livor mortis pada kelinci dengan keracunan organofosfat dibandingkan dengan yang tidak keracunan. Terdapat sedikit perbedaan warna livor mortis antara kelinci dengan keracunan organofosfat (ungu kemerahan/livide) dibandingkan dengan yang tidak keracunan (biru keunguan).

\section{SARAN}

Berdasarkan kesimpulan tersebut, beberapa hal dapat disarankan untuk perbaikan dalam penelitian selanjutnya adalah sebagai berikut:

1. Untuk penelitian selanjutnya diharapkan untuk menambah jumlah sampel penelitian.

2. Sebaiknya saat penelitian dilakukan pengamatan secara kontinyu setiap 15 menit untuk mendapatkan perbedaan antara waktu terbentuk dan waktu menetap livor mortis pada setiap kelinci.

3. Untuk penelitian selanjutnya sebaiknya memilih hewan uji dengan berat badan yang sama atau tidak jauh berbeda untuk menghindari bias. 
Thanos, Tomuka, Mallo: Livor pada intoksikasi..

DAFTAR PUSTAKA

1. Howard C, Adelman M. Establishing the Time of Death. In: Forensic Medicine. New York: Infobase Publishing, 2007; p. 20-6.

2. Budiyanto A, Widiatmika W, Sudiono S, Winardi T, Mun'in A, Sidhi, et al. Ilmu Kedokteran Forensik. Jakarta; FKUI, 1997; p. 25-7.

3. Wirasuta IMAG. Analisis Toksikologi Forensik dan Interpretasi Temuan Analisis. Indonesian Journal of Legal and Forensic Sciences. 2008;1(1):4755.

4. Gossel TA, Douglas BJ. Principle of Clinical Toxicology (2nd ed). New York: Raven Press; 1990. P. 133-139.

5. Kushik J, Chandrabhan D. Sources of Exposure to and Public Health Implications of Organophosphate Pesticides. Rev Panam Salud Publica/Pan Am J Public Health. 2003;14(3):172-83.

6. WHO. Suicide and Suicide Prevention in Asia [Internet] 2008 [cited 2015 Oct 2015]. Available from: http://www.who.int/mental_health/res ources/suicide_prevention_asia.pdf

7. WHO. Mental Health and Substance Abuse Facts and Figures [Internet] 2006 [cited 2015 Oct 2015]. Available from: http://www.searo.who.int/en/Section11 74/Section1199/Section1567/Section1 824_8079.htm.

8. WHO. Bahaya Bahan Kimia pada Kesehatan Manusia dan Lingkungan/WHO. Widyastuti P, alih bahasa; Ester M, editor edisi bahasa Indonesia. Jakarta: EGC, 2005.

9. Purwandari R. Toksikologi [Internet] 2012 [cited 2015 Sep 20] Available from: http://dokumen.tips/documents/toksik. html

10. Soemirat J. Toksikologi Lingkungan. Bandung: Gajah Mada University Press; 2003.

11. Winny, Suwindoro. Pengaruh Pestisida Terhadap Lingkungan. Lingkungan dan pembangunan. 1993;13:233-46.

12. WHO in collaboration with United Nation Environment Programme. Public Healthy Impact of Pesticides Used in Agriculture. Geneva; 1990.

13. Arif M, Kuspuji T, Rakhmi S, Wardhani WI, Setiowulan W. Kapita Selekta
Kedokteran Jilid 1 (3rd ed). Jakarta: Media Aesculapius, 1999.

14. Raini M. Toksikologi Pestisda dan Penanganan akibat Keracunan Pesisida. Media Litbang Kesehatan Volume XVII Nomor 3 Tahun 2007. Jakarta: Departemen Kesehatan RI; 2007.

15. Darmono. Toksisitas Pestisida. Materi Kuliah Farmasi Forensik. [Internet] 2003 [cited 2015 Sep 20] Available from:

http://www.geocities.com/farm_forens ik/Toksikologi/Pestisida.doc

16. Asti Y. Faktor-Faktor Yang Berhubungan dengan Keracunan Pestisida Organofosfat, Karbamat Dan Kejadian Anemia pada Petani Hortikultura Di Desa Tejosari Kecamatan Ngablak Kabupaten Magelang [Tesis]. Semarang: Fakultas Kesehatan Masyarakat Universitas Diponegoro; 2008.

17. Joseph F. Insecticides In: Toxicology A Case-oriented Approach. Washington: CRC Press, 2002.

18. WHO. Biological Monitoring of Chemical Exposure in the Workplace. Geneva: World Health Organization; 1996.

19. Williams P. Properties and Effects of Pesticides In: Principle of Toxicology. New York: A Wiley - Interscience Publication; 2000. P. 345-51.

20. Harrington M, Gill FS. Pocket Consultant Occupational Health (3rd ed). New Delhi: Blackwell Science; 1994; p. 150-1.

21. Rao NG. Textbook of Forensic Medicine \& Toxicology (2nd ed). New Delhi: Jaypee Brothers Medical Publishers, 2010; p. 421.

22. Sastroutomo, Soetikno S. Pestisida: Dasar-dasar dan Dampak Penggunaannya. Bandung: PT. Gramedia Pustaka Utama, 1992.

23. DiMaio VJ, DiMaio D. Forensic Pathology (2nd ed). New York: CRC, 2001; p. 43.

24. Idris AM. Saat Kematian. In: Pedoman Ilmu Kedokteran Forensik (1st ed). Jakarta: Bina Rupa Aksara, 1997; p. 53-81.

25. Dix J, Graham M. Time of Death, Decomposition and Identification an Atlas. New York: CRC Press, 2000; p. 
10-27.

26. Apuranto H, Hoediyanto. Buku Ajar Ilmu Kedokteran Forensik dan Medikolegal. Surabaya: Bagian Ilmu Kedokteran dan Medikolegal Fakultas Kedokteran Universitas Airlangga, 2007.

27. Tsokos M. Forensic Pathology Reviews Volume 3. New Jersey: Humana Press, 2005; p. 191.

28. Rayamane AP, Kumar MP, Nanandkar SD, Chavan GS, Bhise SS, Dayananda R. Medicolegal Significance of Postmortem Lividity in Determination of Time since Death. Journal of Forensic Medicine \& Toxicology. 2014;31:15.
29. Lu FC. Toksikologi Dasar (2nd ed). Jakarta: Penerbit Universitas Indonesia, 1995; p. 328-9.

30. Gani MH. Catatan Materi Kuliah Ilmu Kedokteran Forensik. Padang: Bagian Kedokteran Forensik Universitas Andalas, 2001; p. 111-39.

31. Sofwan D. Ilmu Kedokteran Forensik Pedoman bagi Dokter dan Penegak Hukum. Semarang: Badan Penerbit Universitas Diponegoro, 2000; p. 54-5.

32. Ferryal B. Perkiraan Saat Kematian dan Aspek Medikolegalnya. Jakarta: Bagian Forensik dan Medikolegal FKUI, 2005. 